\title{
Management of ICCT underlying Technologies used for Digital Service Innovation
}

\author{
P. S. Aithal ${ }^{1}$, \& Shubhrajyotsna Aithal ${ }^{2}$ \\ ${ }^{1}$ Srinivas Institute of Management Studies, Srinivas University, Mangalore - 575 001, India \\ OrcidID:0000-0002-4691-8736;E-mail:psaithal@gmail.com \\ ${ }^{2}$ Faculty, College of Engineering \& Technology, Srinivas University, Mangalore, India \\ OrcidID: 0000-0003-1081-5820; E-mail: shubhraaithal@gmail.com
}

Area/Section: Management Science.

Type of the Paper: Research Paper.

Type of Review: Peer Reviewed as per $|\mathrm{C}| \mathrm{O}|\mathrm{P}| \mathrm{E} \mid$ guidance.

Indexed in: OpenAIRE.

DOI: http://doi.org/10.5281/zenodo.3591139.

Google Scholar Citation: IJMTS.

\section{How to Cite this Paper:}

Aithal, P. S. \& Aithal, Shubhrajyotsna. (2019). Management of ICCT underlying Technologies used for Digital Service Innovation. International Journal of Management, Technology, and Social Sciences (IJMTS), 4(2), 110-136. DOI: http://doi.org/10.5281/zenodo.3591139.

International Journal of Management, Technology, and Social Sciences (IJMTS) A Refereed International Journal of Srinivas University, India.

IFSIJ Journal Impact Factor for $2018=4.764$

(C) With Authors.

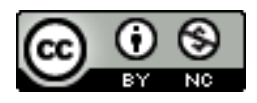

This work is licensed under a Creative Commons Attribution-Non-Commercial 4.0 International License subject to proper citation to the publication source of the work.

Disclaimer: The scholarly papers as reviewed and published by the Srinivas Publications (S.P.), India are the views and opinions of their respective authors and are not the views or opinions of the SP. The SP disclaims of any harm or loss caused due to the published content to any party. 


\title{
Management of ICCT underlying Technologies used for Digital Service Innovation
}

\author{
P. S. Aithal ${ }^{1}$, \& Shubhrajyotsna Aithal ${ }^{2}$ \\ ${ }^{1}$ Srinivas Institute of Management Studies, Srinivas University, Mangalore - 575 001, India \\ OrcidID:0000-0002-4691-8736;E-mail: psaithal@gmail.com \\ ${ }^{2}$ Faculty, College of Engineering \& Technology, Srinivas University, Mangalore, India \\ OrcidID: 0000-0003-1081-5820; E-mail: shubhraaithal@gmail.com
}

\begin{abstract}
Information Communication and Computation Technology (ICCT) also called as Digital Technology and is considered as a general purpose universal technology due to its ability to solve many problems in the human society related to basic needs, advanced wants, and dreamy desires. In this chapter, initially, we have identified various quality attributes of Digital Service and some prominent published works in digital service innovation. The important underlying technologies of ICCT which are emerging as technologies of $21^{\text {st }}$ century including Artificial intelligence \& robotics, Big data \& business analytics, Cloud computing\& storage, Digital marketing, 3D printing, Internet of Things, Online ubiquitous education, Quantum computing, Information storage technology, and Virtual \& Augmented Reality are considered for possible innovations in such industries. The applications of ICCT underlying technologies in some of the prominent service industry sectors are identified and the management of ICCT underlying technology usage strategies for digital service innovation in tertiary sector industries are analysed.
\end{abstract}

Keywords: ICCT, Digital technologies, Universal technology, Digital service innovation, Tertiary industry sector.

\section{INTRODUCTION :}

\subsection{Business \&Technology:}

Doing anything with profit motivation is considered as business. Profit may be tangible or intangible based on some kind of resources which include, money, material, machine, men, information, or time. All business organizations are profit motivated and have the objective of earning long term sustainable profit. Business entities are divided into four types of industry sectors called the primary industry sector, secondary industry sector, tertiary industry sector, and quaternary industry sector. Primary industry sector consists of business entities which produce raw materials for secondary industry sectors like agricultural industry, mining industry, fisheries industry, etc. Secondary industry sector converts raw materials into finished tangible products called goods and is includes all manufacturing industries like food processing, automobiles, cement, steel, computer hardware, Electronic devices, etc. Tertiary industry sector consists of all services industries which provide intangible services to the customers like banking, insurance, tourism, education, healthcare, legal services, etc. Quaternary industry sector consists of supporting services to all other three types of industry sectors which include information technology services, research \& development, business consulting, etc.Doing business in the society can be influenced by various things but adopting technology in business and managing it effectively increases the productivity, efficiency, and hence the profit from the business. Technology is an application of science in systematic way to solve many complicated challenges in the society to make human life comfortable and happy. Certain technologies have grown and expanded their branches to 
many areas and sectors of practice in such a way that they have been designated as GeneralPurpose Technologies. Such general purposetechnologies are identified and used in many industries to do business and to solve or simplify the problems of industries. General Purpose Technologies' (GPT) are characterized by pervasiveness where they have an inherent potential for technical improvements, and innovation complementarities, meaning that through innovative research and development the productivity of industry sectors can be increased [1].

A general-purpose technology or GPT is a term coined to describe a new method of producing and inventing that is important enough to have a protracted aggregate impact. Electricity and information technology (IT) probably are the two most important GPTs until the $20^{\text {th }}$ century. A GPT can be a product, a process, technology or an organisational system. Whole eras of technical progress and growth appear to be driven by a few 'General Purpose Technologies' (GPT's), such as the steam engine, the electric motor, and semiconductors. GPT's are characterized by pervasiveness to many sectors, inherent potential for technical improvements, and innovation complementarities to many applications, giving rise to increasing scale of operation. Economist Richard Lipsey and Kenneth Carlaw [2] suggested that there have only been 24 technologies in history that have been identified as true GPTs. They define a transforming GPT follows four criteria which are listed below [3]:

(1) GPT is a single, recognizable generic technology.

(2) Initially, GPT has much scope for improvement but comes to be widely used across the economy.

(3) GPT has many different uses in many areas to solve problems or to provide comfortability.

(4) GPT creates many spill over effects to spread its base to many sectors.

General purpose technologies have the potential to reshape the economy of the world and boost productivity across all sectors and industries. Such transformations are far more than simple technical innovation, or a new discovery.
However, such technologies often require a wholesale remaking of infrastructure environments, of business models, and of cultural norms. There are three fundamental features of GPTs that differentiate them from other technologies which are (1) Pervasiveness The GPT should spread to most sectors. (2) Improvement - The GPT should get better over time and, hence, should keep lowering the costs of its users. (3) Innovation spawning - The GPT should support to invent and produce new products or processes. Most technologies possess each of these characteristics to some degree, and thus a GPT cannot differ qualitatively from these other technologies [1].

A new research method called Ideal System analysis is developed based on identifying the research gap by comparing present characteristics and ideal characteristics of a system [4]. Ideal system refers to the system which has ideal characteristics i.e., perfect in every way. It is what the mind pictures as being perfect. The characteristics of the present system can be improved towards the characteristics of the ideal system by doing research and innovation. Accordingly, the ideal business model is developed to specify the ideal characteristics of business under input characteristics, output characteristics, system requirement, market conditions, and are can be explained based on their effectiveness in improving the revenue and creating value to the stakeholders [5].Similarly, an ideal technology is defined as a system with ideal characteristics to solve all problems of human beings including both basic needs and advanced wants to support comfort living to realize their dreams. Based on various factors which decide the ideal technology system characteristics, a model consisting of input conditions, output conditions, environmental conditions, and system requirements are identified and analyzed [6].

1.2 Service as Intangible Product /Asset of Service Industries :

Companies in the service industry provideprofessional work called service performed in an expert manner by an individual or team for the benefit of its customers. The typical service businessprovides intangible 
products, such as accounting, banking, education, insurance, health treatment, transportation services, computer services, restaurants, tourism, etc.

The service industries can be innovative and quality and other related attributes of services can be improved to satisfy the service providers and end consumers by means of using a new business method or by means of new technology. Information Communication \& Computation Technology (ICCT) is one kind of general purpose universal technology for the $21^{\text {st }}$
Century which can be used to innovate services of the service industry. ICCT is used as digital technology in the services industry sector to provide and enhance values of various services offered in business management in the society. The attributes of service like method, quality,accuracy, timeliness, efficiency, effectiveness of various services provided are affecting the business management of service industry organizations.

Table 1 : Various attributes used to evaluate service quality in the business field

\begin{tabular}{|l|l|l|l|}
\hline S. No. & Attributes & Type & Explanation \\
\hline 1 & Content & Intangible & $\begin{array}{l}\text { Content of the service is the useful information } \\
\text { contained in the service to the user. }\end{array}$ \\
\hline 2 & Method & Intangible & $\begin{array}{l}\text { Method of a service is the procedure to adopt the } \\
\text { service by the user. }\end{array}$ \\
\hline 3 & Quality & Intangible & $\begin{array}{l}\text { Quality of service is a description or measurement of } \\
\text { the overall performance of service. }\end{array}$ \\
\hline 4 & Accuracy & Intangible & $\begin{array}{l}\text { Accuracy of a service implies how close a measurement } \\
\text { comes to its true value. }\end{array}$ \\
\hline 5 & Timeliness & Intangible & $\begin{array}{l}\text { Availability and accessibility of service in time to get } \\
\text { the full benefit of the service by the customers. }\end{array}$ \\
\hline 6 & Frequency & Intangible & $\begin{array}{l}\text { Number of times the service is provided to the user } \\
\text { during a given period of time. }\end{array}$ \\
\hline 8 & Reed & Intangible & $\begin{array}{l}\text { How quick the service is reachable to the end user. } \\
\text { Ability to perform expected objective for a given time } \\
\text { period and to meet the expectation of the customers. }\end{array}$ \\
\hline
\end{tabular}

1.3 Digital Service :

Digital service is an automated service delivered using digital technologies via the internet, or an electronic communication network. Digital service is usually automated and its supply involves only minimal human intervention.The essential characteristics of digital service include [7-9] : (1) intangibility, (2) high technology, (3) invariance, and (4) scalability. The efficiency and the effectiveness of digital service are measured using many attributes in addition to attributes of a service. These quality attributes of digital service are determined using focus group method [10] and are listed in table 1, which include:Safe \& Secure, Ubiquitous, Simple \& Easy, Customizable, Flexibility, Adaptability, Reusability, and Innovability as shown in figure 1.
(1) Safe \&Secure: Services which are developed using digital technology should be safe to use at development and usage stage for the provider and the consumer respectively so that fearless usage is expected. Further, the services developed using digital technology should protect the data and information, as well as the consequence benefits of the service, should be secured for considerably long time.

(2) Ubiquitous: Offering the service and availing the service anywhere globally, at any time throughout the day, and any amount of time continuously.

(3) Simple \&Easy: Need simple and easy processes to communicate, offer, and use the service by everyone without implementation \& understanding difficulty.

(4) Customizable: Ability to adapt to any system by making suitable changes, or ability to 
adapt to any customer for their variable environment and variable background.

(5) Flexibility: Digital service offered electronically can be stored and retrieved at any time and it can be used or processed online or periodically depending on the end users comfortability. Thus, the flexibility of digital services offers anytime, anywhere, and any amount of time usage opportunity. Further, such services are flexible in terms of processing further at any stage to add value.

(6) Adaptability: It is the ability of digital service to withstand, to sustain, and to respond to the demands and changes of the moment. When the applications change, the servicewith the strength of Adaptability easily adapts and changes like flexibility.

(7) Reusability: Digital services are reusable platforms typically contains extra functionality that could be reused in future requirements. This encourages digital services due to their extra capabilities built around possible future service usage scenarios.

(8) Innovability: Innovability is an ability of a service to adopt innovation either through (i) improvements in the processes of the service leading to new service model or (ii) improvements in technology adopted in the service \& its delivery leading to a radical change in the quality of the service.

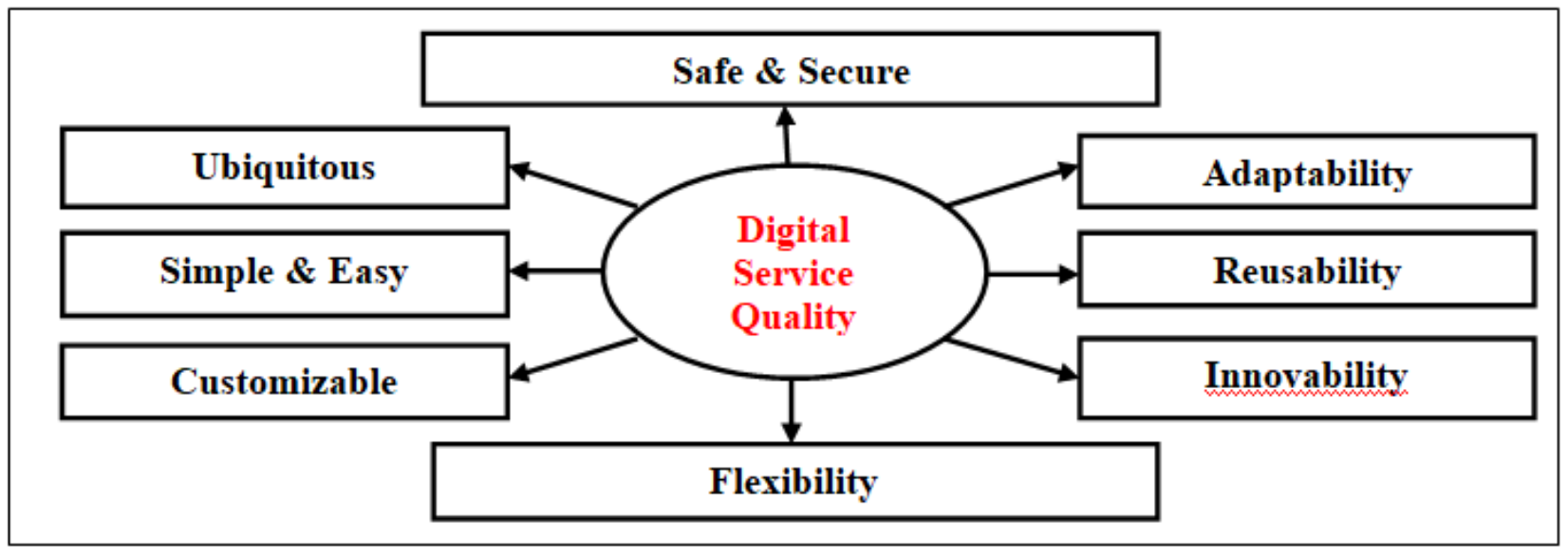

Fig. 1 : Block diagram representing the various quality attributes of Digital Service.

\subsection{Digital Service Innovation :}

A digital service innovation benefits for both the service providersand service receivers called customers and it improves the competitive edge of the service provider. Digital service innovation is an effort of adding novelty in the existing process of a service product or service process that is based on usage of some digital technology systematically for the enhanced comfortability of the customers and business providers. Innovation is a culture of adding value to an existing system by means of creative thinking and it leads to adding further economic and social value in terms of its users and by doing so, it generates new or improved products, services, or processes. Many researchers working on various aspects of digital service innovation and some of the important scholarly publications are reviewed and listed in table 2.

Table 2 : Some of the related works in digital service innovation

\begin{tabular}{|l|l|l|l|}
\hline $\begin{array}{l}\text { S. } \\
\text { No. }\end{array}$ & $\begin{array}{l}\text { Issues on Digital Service } \\
\text { Innovation }\end{array}$ & Focus & Reference \\
\hline 1 & $\begin{array}{l}\text { Service innovation in the digital } \\
\text { age }\end{array}$ & $\begin{array}{l}\text { key contributions and future } \\
\text { directions }\end{array}$ & $\begin{array}{l}\text { Barrett, M., (2015) } \\
{[11]}\end{array}$ \\
\hline 2 & Digital innovation strategy & A framework for diagnosing and & Nylén, D., (2015) \\
\hline
\end{tabular}


International Journal of Management, Technology, and Social

\begin{tabular}{|c|c|c|c|}
\hline & & $\begin{array}{l}\text { improving digital product and } \\
\text { service innovation. }\end{array}$ & {$[12]$} \\
\hline 3 & $\begin{array}{l}\text { Information technology and } \\
\text { product/service innovation }\end{array}$ & $\begin{array}{l}\text { A brief assessment and some } \\
\text { suggestions for future research }\end{array}$ & $\begin{array}{l}\text { Nambisan, S. (2013) } \\
\text { [13] }\end{array}$ \\
\hline 4 & $\begin{array}{l}\text { Exploring digital service } \\
\text { innovation process }\end{array}$ & $\begin{array}{l}\text { Innovation process through value } \\
\text { creation }\end{array}$ & Häikiö, J. (2016) [14] \\
\hline 5 & Service innovation & Disruptive digital innovation & $\begin{array}{l}\text { Agarwal, R. et } \\
\text { al.(2015). [15] }\end{array}$ \\
\hline 6 & Service sector innovation & $\begin{array}{lll}\text { Understanding service } & \text { sector } \\
\text { innovation } & & \\
\end{array}$ & $\begin{array}{l}\text { Sheehan, J. (2006) } \\
{[16]}\end{array}$ \\
\hline 7 & IT-related service innovation & Signs and practices as resources & $\begin{array}{lll}\text { Löbler, H., et } \\
\text { al.(2014) [17] }\end{array}$ \\
\hline 8 & $\begin{array}{l}\text { Product-service innovation and } \\
\text { performance }\end{array}$ & $\begin{array}{l}\text { The role of collaborative } \\
\text { partnerships and } R \& D \text { intensity }\end{array}$ & $\begin{array}{l}\text { Bustinza, O. F. et } \\
\text { al.[2019][18] }\end{array}$ \\
\hline 9 & Digital public service innovation & Framework proposal & $\begin{array}{lll}\text { Bertot, J. C., et } \\
\text { al.(2016) [19] }\end{array}$ \\
\hline 10 & $\begin{array}{l}\text { Disruptive innovation in health } \\
\text { care delivery }\end{array}$ & $\begin{array}{l}\text { A framework for business-model } \\
\text { innovation }\end{array}$ & $\begin{array}{ll}\text { Hwang, J., et } \\
\text { al.(2008) [20] }\end{array}$ \\
\hline 11 & Flexible generification & $\begin{array}{l}\text { ICT standardization strategies and } \\
\text { service innovation }\end{array}$ & $\begin{array}{l}\text { Hanseth, O., (2015). } \\
\text { [21] }\end{array}$ \\
\hline 12 & Servic & $\begin{array}{l}\text { Technology innovation for the } \\
\text { service business }\end{array}$ & $\begin{array}{l}\text { Voudouris, } \\
\text { (2007). [22] }\end{array}$ \\
\hline 13 & $\begin{array}{llr}\begin{array}{l}\text { Incremental and } \\
\text { innovation }\end{array} & \text { radical } \\
\end{array}$ & $\begin{array}{l}\text { Design research vs. technology } \\
\text { and meaning change }\end{array}$ & $\begin{array}{l}\text { Norman, D. A., } \\
\text { (2014). [23] }\end{array}$ \\
\hline 14 & Digital business innovation & $\begin{array}{l}\text { Trends and challenges in digital } \\
\text { business innovation }\end{array}$ & $\begin{array}{l}\text { Morabito, } \\
\text { (2014). [24] }\end{array}$ \\
\hline 15 & ICT based service innovation & $\begin{array}{l}\text { A challenge for project } \\
\text { management }\end{array}$ & $\begin{array}{l}\text { Bygstad, B., (2009). } \\
\text { [25] }\end{array}$ \\
\hline 16 & $\begin{array}{lccr}\begin{array}{l}\text { Innovation } \\
\text { competency } \\
\text { organisation }\end{array} & \text { of } & \text { the } & \begin{array}{r}\text { core } \\
\text { service }\end{array} \\
\end{array}$ & $\begin{array}{l}\text { The role of technology, } \\
\text { knowledge and networks }\end{array}$ & $\begin{array}{l}\text { Kandampully, } \\
\text { (2002). [26] }\end{array}$ \\
\hline 17 & $\begin{array}{l}\text { Key service innovation drivers } \\
\text { in the tourism sector }\end{array}$ & $\begin{array}{l}\text { Empirical evidence } \\
\text { managerial implications }\end{array}$ & $\begin{array}{l}\text { Jiménez-Zarco, et al } \\
\text { (2011). [27] }\end{array}$ \\
\hline 18 & $\begin{array}{l}\text { How big data analytics enables } \\
\text { service innovation }\end{array}$ & $\begin{array}{l}\text { materiality, affordance, and the } \\
\text { individualization of service }\end{array}$ & $\begin{array}{l}\text { Lehrer, C., et al. } \\
\text { (2018). [28] }\end{array}$ \\
\hline 19 & Service innovation & Using the Internet of things & Xu, X. (2012). [29] \\
\hline 20 & $\begin{array}{l}\text { Shaping, organizing and } \\
\text { rethinking service innovation }\end{array}$ & A multidimensional framework & $\begin{array}{l}\text { Rubalcaba, L.,et al. } \\
\text { (2012). [30] }\end{array}$ \\
\hline 21 & $\begin{array}{l}\text { Innovation and regulation in the } \\
\text { digital age }\end{array}$ & for new perspectives & $\begin{array}{l}\begin{array}{l}\text { Benghozi, } \\
\text { (2009). }[31]\end{array} \\
\end{array}$ \\
\hline
\end{tabular}

It is observed that service innovation is possible in major two ways which include service model based innovation and technology based innovation. Service model innovation includes providing new model using new processes to offer a service from an organization or service provider to end customers. Technology based service innovation uses digital signal based Information Communication and Computation Technology (ICCT) which is also called digital technologies. In this paper, we discussed the progress in digital technologies and how they can contribute to the digital services innovation and add value to them from both service 
provider and service receiver points of view.

\section{OBJECTIVES OF THE CHAPTER :}

The chapter discusses the concept of using various prominent ICCT underlying technologies in the innovation of digital products of various sectors of the service industry. Being explorative research in nature, the chapter focuses on the following objectives :

(1) To identify various attributes used to evaluate service quality in the business models

(2) To identify quality attributes of digital service using the focus group method.

(3) To identify important underlying technologies of ICCT which are emerging as technologies of the $21^{\text {st }}$ century and to be used for digital services innovation.

(4) To discuss the applications of ICCT underlying technologies in some of the prominent service industry sectors.

(5) To discuss and analyse the management of ICCT underlying technology usage strategies for digital service innovation in tertiary sector industries.

\section{ICCT UNDERLYING TECHNOLOGIES \& THEIR IMPORTANCE :}

In history, many killer applications technologies were invented which were found to be initially less productive and costly but eventually grown as General Purpose Technologies (GPTs). There are many GPTs identified which include the wheel, steam engine, railroad, electricity, semiconductor

electronics, automobile, computer, Internet, mobile phones, Information Communication and Computation Technology (ICCT),
Nanotechnology (NT), etc. Recently, based on the analysis, it is found that two general purpose technologies viz. ICCT \& NT are capable solve many problems of the society especially related to problems of basic needs, problems of advance wants, and problems on dreamy desires of a human being in the society and renamed as Universal Technologies [3]. ICCT, being a digital signal based technology, is responsible for information generation, communication, processing, storing, and retrieval and represents a single unified technology called Information Communication and Computation Technology (ICCT). ICCT is a combined version of Information Communication Technology (ICT) and Computer Technology (CT).In the $21^{\text {st }}$ century, ICCT is grown and spread its roots from primary to tertiary sectors due to its pervasiveness, growth, and innovation opportunity properties [3]. The Improvement and Innovation spawning properties of ICCT is capable to innovate many services offered by service industries and hence capable \& qualified to be called as universal technology. As time progress, during the $21^{\text {st }}$ century, ICCT has created many underlying technologies which were further developed as independent technologies under the umbrella of ICCT as universal technology. The important ICCT underlying technologies which offer general purpose technology characteristics including pervasiveness, growth oriented, and innovation opportunity and hence have potential to make digital service innovations to a high extent are listed in table 3.

Table 3 : ICCT underlying technologies, their objectives, and ultimate goal [32], [33]

\begin{tabular}{|c|c|c|c|}
\hline S. No & $\begin{array}{l}\text { Underlying } \\
\text { Technologies of ICCT }\end{array}$ & Objectives & Ultimate Goal \\
\hline 1 & $\begin{array}{l}\text { Artificial Intelligence } \\
\text { Technology }\end{array}$ & $\begin{array}{l}\text { Performing by thinking and doing } \\
\text { things better than human beings }\end{array}$ & $\begin{array}{l}\text { Ideal artificial brain \& } \\
\text { connecting brains with } \\
\text { computers }\end{array}$ \\
\hline 2 & $\begin{array}{l}\text { Big data and Business } \\
\text { Analytics }\end{array}$ & $\begin{array}{l}\text { Developing effective information using } \\
\text { hidden patterns, unknown correlations, } \\
\text { market trends, and customer } \\
\text { preferences to help organizations for } \\
\text { making better business decisions }\end{array}$ & $\begin{array}{ll}\text { Ideal } & \text { Business } \\
\text { prediction [5] } & \end{array}$ \\
\hline
\end{tabular}


International Journal of Management, Technology, and Social

\begin{tabular}{|c|c|c|c|}
\hline 3 & $\begin{array}{l}\text { Cloud Computing } \\
\text { Technology }\end{array}$ & $\begin{array}{l}\text { Using computer infrastructure at cost } \\
\text { effective and optimum level from } \\
\text { ubiquitous location }\end{array}$ & Ideal Computer [4] \\
\hline 4 & $\begin{array}{l}\text { Digital Business \& } \\
\text { Marketing }\end{array}$ & $\begin{array}{l}\text { Ubiquitous mobile business and e- } \\
\text { marketing using digital and internet } \\
\text { technology }\end{array}$ & Ideal Business [5, 34] \\
\hline 5 & 3D printing Technology & $\begin{array}{l}\text { Preparing three dimensional structures } \\
\text { from a digital file. This is achieved } \\
\text { using additive processes using less } \\
\text { material than traditional manufacturing } \\
\text { methods }\end{array}$ & $\begin{array}{l}\text { Ideal Production of } \\
\text { components \& Devices }\end{array}$ \\
\hline 6 & Internet of Things (IoT) & $\begin{array}{l}\text { Interconnection and integration of the } \\
\text { physical world and the cyber space } \\
\text { remotely to control the devices from } \\
\text { distance }\end{array}$ & $\begin{array}{l}\text { Ideal interconnection \& } \\
\text { Control }\end{array}$ \\
\hline 7 & $\begin{array}{l}\text { Online } \quad \text { Ubiquitous } \\
\text { Education \& Training }\end{array}$ & $\begin{array}{l}\text { Education for everybody irrespective } \\
\text { of location, age, economic level using } \\
\text { technology }\end{array}$ & $\begin{array}{l}\text { Ideal education system } \\
{[35,36]}\end{array}$ \\
\hline 8 & $\begin{array}{ll}\text { Optical Computing } \\
\text { Technology }\end{array}$ & High speed data processing & $\begin{array}{l}\text { Ideal Computers [37, } \\
\text { 38] }\end{array}$ \\
\hline 9 & $\begin{array}{ll}\text { Information } & \text { Storage } \\
\text { Technology } & \end{array}$ & $\begin{array}{l}\text { Huge amount of information storage in } \\
\text { a small region using suitable } \\
\text { technology }\end{array}$ & Ideal storage system \\
\hline 10 & $\begin{array}{lcc}\text { Virtual } & \text { Reality } & \& \\
\text { Augmented Reality } & \end{array}$ & $\begin{array}{l}\text { Virtual reality is an immersion } \\
\text { experience which gives the physical } \\
\text { world feelings }\end{array}$ & $\begin{array}{l}\text { Ideal virtual experience } \\
\text { [39] }\end{array}$ \\
\hline
\end{tabular}

\subsection{Artificial intelligence Technology:}

Artificial intelligence (AI) is an area of computer science which focuses on the creation of intelligent machines which can mimic the decisions of human beings. The primary objective of AI technology is to develop machines which can think and do things better than human beings. The main functions of artificial intelligence machines are to recognize the environment such as speech recognition, Learning, Planning, Problem solving, and hence decision making. Artificial intelligence machine mimics cognitive functions of human beings associated with other human minds, such as learning \& memorizing and decision making for problem solving. ICCT has created a platform for AI to be introduced and developed for adding intelligent thinking components in electronic systems used in any industrial sectors. Artificial intelligence has its applications in almost all industries in the primary sector, secondary sectors, tertiary sectors, and quaternary sector.

\subsection{Big data \&Business analytics:}

The emerging subfield of ICCT named big data and business analytics focus on handling huge amount of data continuously generated in any business or data capturing process and analyses it using various quantitative analytical techniques and mathematical models to study the pattern and descriptive information, predictive information, and prescriptive information for supporting the decision makers to take optimum decisions to the problems related to future aspects of the business. Predictive analytics in various functional areas like Marketing analytics, Retail Analytics (Customer Analytics / Supply Chain Analytics), Pricing Analytics, Financial analytics, Social media analytics, sports analytics, and Healthcare analytics are finding importance in the business environment for effective decision making. Further Prescriptive Analytics for optimizing the decisions with multiple objectives / portfolio analytics, optimizing complex decisions / sales 
force analytics, and Retail Analytics, etc are also have a futuristic impact on effective business decisions.

\subsection{Cloud Computing:}

Cloud computing is one of the advances in computer technology and is uses information communication technology as well. Due to the ubiquity of cloud computing facility with flexibility in scaling it has become an important topic of research and provides the value for computing processes in the business. The cloud computing model also provides a most important application called Business Intelligence (BI) for effective decision making in business processes via the Internet. Cloud computing model provides its clients with both hardware as well as software to process the data and information online as a rental service. Cloud computing model has three variations as Software as a Service (SaaS), Infrastructure-as-a-Service (IaaS) and Platform-as-a-Service (PaaS) to provide ubiquitous computing service solutions to the business. The cloud computing solution used by any business will allow companies to reduce their investment cost, maintenance cost, and hence business cost without compromising to have access to BI solution which will give the business an edge on their competition. Could computing is a subfield of the Information Communication and Computation Technology (ICCT).

\subsection{Digital Business \&Marketing:}

ICCT created a new business model called Ebusiness/ M-business model. This model consists of the ubiquitous selling proposition. Digital marketing is the marketing of products or services using digital technologies as per such new business model using mainly on the Internet, but also including mobile phones, display advertising, and any other digital medium.

Digitalmarketing technology represents advertisements delivered through digital channels and internet including search engines, websites, social media, email, and mobile apps. Digital business and marketing are emerged as an essential future business \&marketing activity using ICCT general purpose technology.

\subsection{D Printing:}

3D printing is an ICCT application where various materials are joined or solidified using various processes under the control of the computer to create a three-dimensional object. In 3D printing, an object is created by laying down successive layers of material until the object is created. 3D printing can be divided into metal, fabrics, bio and a whole host of other industries with many applications in many industries worldwide.3D printing is a variant of ICCT general purpose technology and has wide scope in various industrial automation and home automation processes. 3D printing technology is expected to revolutionize material fabrication processes. 3D printing comprises of many other technologies along with ICCT. Some of the 3D printers make use of nanomaterials and nanocomposites for anything, anywhere manufacturing.

\subsection{Internet of Things:}

It is a network of various electronic, computing, and optical devices/objects including human beings connected virtually by means of internet or intranet for enabling them to send and receive data and information. These objects are provided with unique identifiers (UIDs) and are capable to transfer data and information over a network without requiring human-to-human or human-tocomputer interaction by using IoT technology. Such a connection of physical things/objects to the Internet makes it possible to access remote sensor data and to control the physical world from a distance. The mash-up of captured data with data retrieved from other sources, eg, with data that is contained in the Web, gives rise to a new synergistic service that go beyond the services that can be provided by an isolated embedded system. Internet-of-Things (IoT) is not in any new disruptive technology but is the pervasive deployment and innovation of ICCT.

\subsection{Online Ubiquitous Education:}

To provide education to everybody, the transformation of traditional campus based education system into Massive Online Open Courses (MOOC) system is essential. Even though initially MOOC is considered as complementary to traditional campus based education HE system, as time progress, it may 
replace campus based HE system completely. Higher education focuses on enhancing knowledge, skills, experience, and hence confidence to make innovations and better decisions can be offered equally effective through online using wireless video channels. Ubiquitous online education offered through multidisciplinary areas using simulation may out pass the traditional laboratory based education in the HE system. The other underlying ICCT technologies also support online ubiquitous education system to make it more effective, efficient and easily accessible system for everybody without their geographical locations and economic conditions. Some of such growing brands includeEDX, COUSERA, NPTEL, SWAYAM, etc.

\subsection{Optical Computing:}

High speed computers based on optical signal switching and optical signal processing are expected to a breakthrough with their full potentials and capabilities using optical logic gates and flip-flops fabricated by nanocomposites are expected to breakthrough in this century. High speed computation and data storage using nanotechnology based optical computers are going to revolutionize the entire computer industry. Optical computation is joining both general purpose technologies of Nanotechnology and ICCT through the processes of design \& production as well as operation \& applications respectively. Various optical principles like photo-refraction, optical spatial solitons, and optical logic gates are under considerations for building all-optical computers.

\subsection{Information Storage Technology :}

Information storage technology supports to develop devices to store \& retrieve information in digital format. The trend in this field is to enhance the capability of devices to store huge amount of information in a small region at high speed and low cost. Various storage devices used and under consideration include Semiconductor Storage, Hologram Storage, Optical Storage, DNA Based Digital Storage, etc. which should have capability to store information in Terabytes, Petabytes, Exabytes, Zettabyte, and even Yottabyte in order to cater the forthcoming information storage applications.

\subsection{Virtual \& Augmented Reality :}

Virtual reality is an artificial environment that is created with the help of computer-based software and presented to the user in such a way that the user suspends belief and accepts it as a real environment. On a computer, virtual reality is primarily experienced through two of the five senses: sight and sound. Currently, the virtual reality is mainly developed and used in simulated training and education as well as the simulated game environment. But it may further find its applications in many other areas including business as augmented reality and may enter the group of general purpose technology.

ICCT has many applications in the many Industries and Industry sectors. Almost all Industries and industry sectors belonging to Primary, Secondary, Tertiary, and Quaternary Industry Sectors are basically supported by and get benefits from ICCT. In next section, the applications of ICCT underlying technologies in some of important service industry sectors are discussed.

\section{DIGITAL SERVICE STRATEGY IN TERTIARY INDUSTRY SECTOR :}

Industries and industry sectors in tertiary sector called services sector are expected to get benefit from ICCT. Table 4 lists some of the services sector gets benefit from underlying technologies of ICCT.

Table 4: Some applications of ICCT in Tertiary Industry Sector

\begin{tabular}{|l|l|l|}
\hline $\begin{array}{l}\text { S. } \\
\text { No. }\end{array}$ & $\begin{array}{l}\text { Underlying } \\
\text { technologies of ICCT }\end{array}$ & Applications in Tertiary Industry Sector \\
\hline 1 & $\begin{array}{l}\text { Artificial Intelligence } \\
\text { Technology }\end{array}$ & $\begin{array}{l}\text { Artificial Intelligence technology is used in many areas of service } \\
\text { industry sector including tourism, telecommunications, citizen } \\
\text { services, Banking sector for loan decisions, retail sector, etc. [40-44] }\end{array}$ \\
\hline
\end{tabular}




\begin{tabular}{|c|c|c|}
\hline 2 & $\begin{array}{l}\text { Big data and Business } \\
\text { Analytics }\end{array}$ & $\begin{array}{l}\text { In Supply chain management, Banking sector, Tourism sector, health } \\
\text { sector, financial \& insurance sector, fashion industry, } \\
\text { [45-49]. }\end{array}$ \\
\hline 3 & $\begin{array}{l}\text { Cloud Computing } \\
\text { Technology }\end{array}$ & $\begin{array}{l}\text { Financial service industry, Education industry, Security industry, } \\
\text { Brokering service, Healthcare, Gamming industry, Supply-chain } \\
\text { industry, Telecommunication industry, } \\
{[50-52]}\end{array}$ \\
\hline 4 & $\begin{array}{l}\text { Digital Business \& } \\
\text { Marketing }\end{array}$ & $\begin{array}{l}\text { Digital Marketing and customer relationship in all kind of industry } \\
\text { including hotel industry, tourism industry, health industry etc. [53- } \\
54 \text { ] }\end{array}$ \\
\hline 5 & $\begin{array}{ll}\text { 3D } & \text { printing } \\
\text { Technology } & \end{array}$ & Health sciences, Forest industry, [55-56] \\
\hline 6 & $\begin{array}{l}\text { Internet of Things } \\
\text { (IoT) }\end{array}$ & $\begin{array}{l}\text { Service innovations are possible using IoT. Smart city services } \\
\text { including Tourism, Healthcare, Telecommunication, Logistics, } \\
\text { Transportation, Retail, etc. [57-61] }\end{array}$ \\
\hline 7 & $\begin{array}{l}\text { Online Ubiquitous } \\
\text { Education \& Training } \\
\text { Technology }\end{array}$ & $\begin{array}{l}\text { Education industry, Library services, Retail banking, Healthcare } \\
\text { services, etc. [62-64] }\end{array}$ \\
\hline 8 & $\begin{array}{l}\text { Optical Computing } \\
\text { Technology }\end{array}$ & $\begin{array}{l}\text { Optical technology based high speed computers are essential in future } \\
\text { Retail industry sectors, Logistics \& Supply chain industry sectors, } \\
\text { Telecom industry sector, Information security industry, etc. [65-66] }\end{array}$ \\
\hline 9 & $\begin{array}{ll}\text { Information } & \text { Storage } \\
\text { Technology } & \end{array}$ & $\begin{array}{l}\text { All services industry sectors where huge amount data and } \\
\text { information related to the business are to be stored and retrieved at } \\
\text { high speed in small device. }\end{array}$ \\
\hline 10 & $\begin{array}{l}\text { Virtual Reality \& } \\
\text { Augmented Reality }\end{array}$ & $\begin{array}{l}\text { Education \& Training, Tourism, Travel industry, Finance, etc. [67- } \\
\text { 69] }\end{array}$ \\
\hline
\end{tabular}

ICCT underlying technologies are considered as emerging breakthrough technologies ofthe $21^{\text {st }}$ century with many types of innovative applications in all industrial sectors. When service sector industries are concerned, there are many opportunities to radically change the service models, service methods, service processes, service development, service transformation, service utilization, and service feedback. The entire lifecycle of the service as an output product of service industries and as an intangible input resource for the customers can be modified using ICCT digital technologies. The emerging underlying technologies of ICCT are so powerful and innovative so that they are really capable to destruct the existing models and methods of offering the services as disruptive technologies and able to create new avenue to realize the ambitious wants and dreamy desires of the customers. Tables 5 list some of the prominent service industries and the predicted ICCT underlying technologies which may re-define the way the services are offered by different service industries.

Table 5 : ICCT based Service Innovation in Tertiary Industry Sector

\begin{tabular}{|l|l|l|}
\hline $\begin{array}{l}\text { S. } \\
\text { No. }\end{array}$ & Service Industries & Applications of ICCT digital technology for service innovation \\
\hline 1 & Advertising industry & $\begin{array}{l}\text { Artificial Intelligence Technology, Big data and Business Analytics, } \\
\text { Cloud Computing Technology, Internet of Things (IoT), Online } \\
\end{array}$ \\
& & $\begin{array}{l}\text { Ubiquitous Education \& Training Technology, Optical Computing } \\
\text { Technology, Information Storage Technology, Virtual Reality \& } \\
\text { Augmented Reality. }\end{array}$ \\
\hline 2 & Education industry & Artificial Intelligence Technology, Big data and Business Analytics, \\
\hline
\end{tabular}




\begin{tabular}{|c|c|c|}
\hline & & $\begin{array}{l}\text { Cloud Computing Technology, Digital Business \& Marketing, 3D } \\
\text { printing Technology, Internet of Things (IoT), Online Ubiquitous } \\
\text { Education \& Training Technology, Information Storage } \\
\text { Technology, Virtual Reality \& Augmented Reality. }\end{array}$ \\
\hline 3 & E-Commerce industry & $\begin{array}{l}\text { Artificial Intelligence Technology, Big data and Business Analytics, } \\
\text { Cloud Computing Technology, Digital Business \& Marketing, } \\
\text { Information Storage Technology, Virtual Reality \& Augmented } \\
\text { Reality. }\end{array}$ \\
\hline 4 & Entertainment industry & $\begin{array}{l}\text { Cloud Computing Technology, Digital Business \& Marketing, 3D } \\
\text { printing Technology, Internet of Things (IoT), Online Ubiquitous } \\
\text { Education \& Training Technology, Information Storage } \\
\text { Technology, Virtual Reality \& Augmented Reality. }\end{array}$ \\
\hline 5 & Fashion industry & $\begin{array}{l}\text { 3D printing Technology, Internet of Things (IoT), Online } \\
\text { Ubiquitous Training Technology, Optical Computing Technology, } \\
\text { Information Storage Technology, Virtual Reality \& Augmented } \\
\text { Reality. }\end{array}$ \\
\hline 6 & $\begin{array}{l}\text { Financial services } \\
\text { industry }\end{array}$ & $\begin{array}{l}\text { Artificial Intelligence Technology, Big data and Business Analytics, } \\
\text { Cloud Computing Technology, Digital Business \& Marketing, 3D } \\
\text { printing Technology, Internet of Things (IoT), Online Ubiquitous } \\
\text { Education \& Training Technology, Optical Computing Technology, } \\
\text { Information Storage Technology, Virtual Reality \& Augmented } \\
\text { Reality. }\end{array}$ \\
\hline 7 & Healthcare industry & $\begin{array}{l}\text { Artificial Intelligence Technology, Big data and Business Analytics, } \\
\text { Cloud Computing Technology, Digital Business \& Marketing, 3D } \\
\text { printing Technology, Internet of Things (IoT), Online Ubiquitous } \\
\text { Education \& Training Technology, Virtual Reality \& Augmented } \\
\text { Reality. }\end{array}$ \\
\hline 8 & Hospitality industry & $\begin{array}{l}\text { Artificial Intelligence Technology, Big data and Business Analytics, } \\
\text { Digital Business \& Marketing, 3D printing Technology, Internet of } \\
\text { Things (IoT), Online Ubiquitous Education \& Training Technology, } \\
\text { Optical Computing Technology, Information Storage Technology, } \\
\text { Virtual Reality \& Augmented Reality. }\end{array}$ \\
\hline 9 & Insurance industry & $\begin{array}{l}\text { Big data and Business Analytics, Cloud Computing Technology, } \\
\text { Online Ubiquitous Education \& Training Technology, Optical } \\
\text { Computing Technology, Information Storage Technology, Virtual } \\
\text { Reality \& Augmented Reality. }\end{array}$ \\
\hline 10 & IT services industry & $\begin{array}{l}\text { Artificial Intelligence Technology, Big data and Business Analytics, } \\
\text { Cloud Computing Technology, Digital Business \& Marketing, } \\
\text { Internet of Things (IoT), Online Ubiquitous Education \& Training } \\
\text { Technology, Optical Computing Technology, Information Storage } \\
\text { Technology, Virtual Reality \& Augmented Reality. }\end{array}$ \\
\hline 11 & Media industry & $\begin{array}{l}\text { Artificial Intelligence Technology, Big data and Business Analytics, } \\
\text { Cloud Computing Technology, Digital Business \& Marketing, } \\
\text { Internet of Things (IoT), Optical Computing Technology, } \\
\text { Information Storage Technology, Virtual Reality \& Augmented } \\
\text { Reality. }\end{array}$ \\
\hline 12 & $\begin{array}{l}\text { Online } \\
\text { industry }\end{array}$ & $\begin{array}{l}\text { Artificial Intelligence Technology, Big data and Business Analytics, } \\
\text { Digital Business \& Marketing, Internet of Things (IoT), Online } \\
\text { Ubiquitous Education \& Training Technology, Optical Computing }\end{array}$ \\
\hline
\end{tabular}




\begin{tabular}{|l|l|l|}
\hline & & $\begin{array}{l}\text { Technology, Information Storage Technology, Virtual Reality \& } \\
\text { Augmented Reality. }\end{array}$ \\
\hline 13 & Public service industry & $\begin{array}{l}\text { Big data and Business Analytics, Cloud Computing Technology, } \\
\text { Internet of Things (IoT), Online Ubiquitous Education \& Training } \\
\text { Technology, Virtual Reality \& Augmented Reality. }\end{array}$ \\
\hline 14 & Retail industry & $\begin{array}{l}\text { Artificial Intelligence Technology, Big data and Business Analytics, } \\
\text { Cloud Computing Technology, Digital Business \& Marketing, } \\
\text { Internet of Things (IoT), Information Storage Technology, Virtual } \\
\text { Reality \& Augmented Reality. }\end{array}$ \\
\hline 15 & Sports industry & $\begin{array}{l}\text { Artificial Intelligence Technology, Big data and Business Analytics, } \\
\text { Cloud Computing Technology, Digital Business \& Marketing, 3D } \\
\text { printing Technology, Internet of Things (IoT), Online Ubiquitous } \\
\text { Training Technology, Virtual Reality \& Augmented Reality. }\end{array}$ \\
\hline 16 & $\begin{array}{l}\text { Tourism industry } \\
\text { Artificial Intelligence Technology, Big data and Business Analytics, } \\
\text { Cloud Computing Technology, Digital Business \& Marketing, 3D } \\
\text { printing Technology, Internet of Things (IoT), Online Ubiquitous } \\
\text { Education \& Training Technology, Optical Computing Technology, } \\
\text { Information Storage Technology, Virtual Reality \& Augmented } \\
\text { Reality. }\end{array}$ \\
\hline 17 & $\begin{array}{l}\text { Travel \& Transport } \\
\text { industry }\end{array}$ & $\begin{array}{l}\text { Artificial Intelligence Technology, Big data and Business Analytics, } \\
\text { Cloud Computing Technology, Digital Business \& Marketing, 3D } \\
\text { printing Technology, Internet of Things (IoT), Information Storage } \\
\text { Technology, Virtual Reality \& Augmented Reality. }\end{array}$ \\
\hline 18 & $\begin{array}{l}\text { Event } \\
\text { industry }\end{array}$ & $\begin{array}{l}\text { Artificial Intelligence Technology, Big data and Business Analytics, } \\
\text { Digital Business \& Marketing, Internet of Things (IoT), Virtual } \\
\text { Reality \& Augmented Reality. }\end{array}$ \\
\hline
\end{tabular}

\section{HOW ICCT UNDERLYING} TECHNOLOGIES USED FOR DIGITAL SERVICE INNOVATION IN THE TERTIARY INDUSTRY SECTOR :

The use of top ten digital technologies under
ICCT in innovating various services offered by some of the prominent service industries are predicted using predictive analysis technique [70-71] and listed in following ten tables from Table 6 to Table 15.

Table 6 : Artificial Intelligence Technology based Service Innovation in Service Industries

\begin{tabular}{|l|l|l|}
\hline $\begin{array}{l}\text { S. } \\
\text { No. }\end{array}$ & Service Industries & Applications of Artificial Intelligence Technology \\
\hline 1 & Advertising industry & $\begin{array}{l}\text { Interactive advertising, Agent mediated advertising, Intelligent } \\
\text { advertising, Pervasive advertising, etc. }\end{array}$ \\
\hline 2 & Education industry & $\begin{array}{l}\text { Knowledge management, Educational cobots and smart classrooms, } \\
\text { Artificial intelligence in auditing, Educational simulations, Online } \\
\text { distributed learning, Improving mobile learning environment }\end{array}$ \\
\hline 3 & E-Commerce industry & $\begin{array}{l}\text { Intelligent Techniques for E-commerce, E-commerce intelligent } \\
\text { agents, Order products online, track orders, and perform other } \\
\text { ecommerce activities using AI, Intelligent e-business models, } \\
\text { Electronic auditing, fuzzy intelligent agents for e-commerce } \\
\text { automation, etc. }\end{array}$ \\
\hline 4 & Entertainment industry & $\begin{array}{l}\text { Adaptive robotics in the entertainment industry, Computer games, } \\
\text { Development of entertainment robot, Entertainment software agents, }\end{array}$ \\
\hline
\end{tabular}




\begin{tabular}{|c|c|c|}
\hline & & c. \\
\hline 5 & Fashion industry & $\begin{array}{l}\text { Sales forecasting for fashion retailing, Fuzzy association rule mining } \\
\text { for fashion product development, intelligent clothes search system } \\
\text { based on fashion styles, Artificial multi-agent system, AI based } \\
\text { designs for fashion industry, Intelligent fashion styling, etc. }\end{array}$ \\
\hline 6 & $\begin{array}{l}\text { Financial services } \\
\text { industry }\end{array}$ & $\begin{array}{l}\text { For managing fraud and identity theft, To advise clients, } \\
\text { Strategicissues for financial services marketing, Prediction of } \\
\text { financial health of organizations using AI, AI to create value in } \\
\text { insurance, Neuro-based AI model for loan decisions, Service } \\
\text { automation using AI, Blockchain techniques, etc. }\end{array}$ \\
\hline 7 & Healthcare industry & $\begin{array}{l}\text { Designing smart health care technology, AI in behavioral and } \\
\text { mental health care, Applying agent technology to healthcare, Remote } \\
\text { monitoring of high-risk patients AI based agent- } \\
\text { mediated healthcare systems, For agent-mediated health care } \\
\text { systems, AI assisted medical reference system, etc. }\end{array}$ \\
\hline 8 & Hospitality industry & $\begin{array}{l}\text { Experience-based travel, AI based service automation, AI based } \\
\text { Yield-management approach to hotel-room pricing, Agent } \\
\text { technologyin hotel business, Exploring customer experiences, Design } \\
\text { of fuzzy expert system for hotel selection, Development of intelligent } \\
\text { robot, etc. }\end{array}$ \\
\hline 9 & IT services industry & $\begin{array}{l}\text { Automation of Software development \& coding, Knowledge } \\
\text { management, Information security services, Semantic web services, } \\
\text { decision automation, etc. }\end{array}$ \\
\hline 10 & Media industry & $\begin{array}{l}\text { Social media analytics and intelligence, Effective knowledge sharing, } \\
\text { Ambient intelligence in multimedia, Restructuring newsroom, AI } \\
\text { based new media model, etc. }\end{array}$ \\
\hline 11 & Retail industry & $\begin{array}{l}\text { Marketing decision making, Multivalent negotiations, Work flow } \\
\text { automation, Marketing intelligence, Price adjustment, Expert systems } \\
\text { with AI, }\end{array}$ \\
\hline 12 & Sports industry & $\begin{array}{l}\text { Sports performance prediction, Automation, Sports informatics, } \\
\text { Emotion calculation based on AI, Sports strategies implementation, } \\
\text { etc. }\end{array}$ \\
\hline 13 & Tourism industry & $\begin{array}{l}\text { Smart tourism, Tourism information technology, Tourism service } \\
\text { automation, Knowledge management, Robotics \&service } \\
\text { automation,Tour itinerary planning, Personalizing recommendations, } \\
\text { Travel recommender system, Tourism forecasting, etc. }\end{array}$ \\
\hline 14 & $\begin{array}{l}\text { Travel \& Transport } \\
\text { industry }\end{array}$ & $\begin{array}{l}\text { Intelligenttransport system using AI, Improving parking efficiencies, } \\
\text { Agent based logistics, Traffic forecasting, Travel time prediction, } \\
\text { Experience based travel, Intelligent agents in traffic, } \\
\text { Swarm intelligence, Technology assisted travel counselling, Artificial } \\
\text { transportation system, etc. }\end{array}$ \\
\hline 15 & $\begin{array}{ll}\text { Event management } \\
\text { industry }\end{array}$ & Automatic computing, Artificial surface development, etc. \\
\hline
\end{tabular}

Table 7 : Big data and Business Analyticsbased Service Innovation in Service Industries

\begin{tabular}{|l|l|l|}
\hline $\begin{array}{l}\text { S. } \\
\text { No. }\end{array}$ & Service Industries & Applications of Big data and Business Analytics \\
\hline 1 & Advertising industry & $\begin{array}{l}\text { Advertising analytics, Privacy and user control, Analytics based } \\
\text { decision making, Big data analytics as service, }\end{array}$ \\
\hline
\end{tabular}




\begin{tabular}{|c|c|c|}
\hline 2 & Education industry & $\begin{array}{l}\text { Analytics for education, Learning analytics, Teaching analytics, } \\
\text { Predictive analytics, Optimizing quality, etc. }\end{array}$ \\
\hline 3 & E-Commerce industry & $\begin{array}{l}\text { E-commerce data analytics, market analytics, Big-data warehouse, } \\
\text { Customer demand \& supply chain analytics, Big data as a service, } \\
\text { Text analytics, Big data driven e-commerce architecture, } \\
\text { Validating e-commerce metrics, Online marketing, Intelligent service } \\
\text { for e-commerce customers, Combating e-commerce identity fraud, } \\
\text { etc. }\end{array}$ \\
\hline 4 & Entertainment industry & $\begin{array}{l}\text { Games analytics, Music based big data analytics, Multimedia } \\
\text { analytics, Branded Entertainment, etc. }\end{array}$ \\
\hline 5 & Fashion industry & Knowledge co-creation, Customer Analytics in Fashion industry, etc. \\
\hline 6 & $\begin{array}{l}\text { Financial services } \\
\text { industry }\end{array}$ & $\begin{array}{l}\text { Detecting fraud, Financial auditing, meta-analytics for risk forecast, } \\
\text { Smarter fraud investigations, financial data modeling and analysis, } \\
\text { etc. }\end{array}$ \\
\hline 7 & Healthcare industry & $\begin{array}{l}\text { Reduce healthcare costs, Predictive analytics, Appointment } \\
\text { brokering, scheduling, e-referral and e- discharge,for better health } \\
\text { planning, Making healthcare green, Clinical Decision Support, }\end{array}$ \\
\hline 8 & Hospitality industry & $\begin{array}{l}\text { Smart hospitality, Knowledge management, Decision support, } \\
\text { Online customer service, etc. }\end{array}$ \\
\hline 9 & Insurance industry & $\begin{array}{l}\text { Customer profitability forecasting, Increasing customer orientation, } \\
\text { Secure cyber incident analytics, Fraud Detection, Knowledge } \\
\text { discovery, Intelligent Multi Agent Systems, etc. }\end{array}$ \\
\hline 10 & Media industry & $\begin{array}{l}\text { Social media analytics,Antecedents and Business } \\
\text { Empathic media and advertising, New business model, }\end{array}$ \\
\hline 11 & Retail industry & $\begin{array}{l}\text { Retail business analytics, intelligent operational dashboards for } \\
\text { smarter commerce, Performance measurement, etc. }\end{array}$ \\
\hline 12 & Sports industry & $\begin{array}{l}\text { Sports analytics, Risk monitoring, Smart clothing, Predictive } \\
\text { analytics on performance, etc. }\end{array}$ \\
\hline 13 & Tourism industry & $\begin{array}{l}\text { Smart tourism, Tourism analytics, Social media analytics in tourism, } \\
\text { Monitoring and forecasting tourist activities, Sentiment analysis, } \\
\text { Forecasting tourism demand, Customer knowledge management, } \\
\text { data analytic tourism dashboard, etc. }\end{array}$ \\
\hline 14 & $\begin{array}{lll}\text { Travel \& } & \text { Transport } \\
\text { industry } & & \end{array}$ & $\begin{array}{l}\text { Travel search engine optimization, Transport analytics, Railway } \\
\text { transportation optimization, Revenue management and } \\
\text { pricing analytics, Passenger travel behaviour, Risk management } \\
\text { using predictive analytics, Smart transportation, Multi-model travel } \\
\text { policies, etc. }\end{array}$ \\
\hline 15 & $\begin{array}{ll}\text { Event management } \\
\text { industry }\end{array}$ & Event risk management, Smart event management, etc. \\
\hline
\end{tabular}

Table 8 : Cloud Computing Technology based Service Innovation in Service Industries

\begin{tabular}{|l|l|l|}
\hline $\begin{array}{l}\text { S. } \\
\text { No. }\end{array}$ & Service Industries & Applications of Cloud Computing Technology \\
\hline 1 & Advertising industry & $\begin{array}{l}\text { Advertising analytics, Mobile advertising, Alphanumeric indexing, } \\
\text { Social media advertisement, etc. }\end{array}$ \\
\hline 2 & Education industry & $\begin{array}{l}\text { Cloud Computing prototypes, Education platforms, Improving } \\
\text { research productivity, Alternative IT sourcing, Value addition to } \\
\text { education project, Micro-learning platforms, E-learning, etc. }\end{array}$ \\
\hline
\end{tabular}




\begin{tabular}{|l|l|l|}
\hline 3 & E-Commerce industry & $\begin{array}{l}\text { SME e-commerce model, E-commerce cloud, } \\
\text { Anti-Counterfeit Scheme, etc. }\end{array}$ \\
\hline 4 & Entertainment industry & $\begin{array}{l}\text { Cloud based smart home, Sounds in cloud, Cloud gaming, Mobile } \\
\text { cloud gaming, Music in cloud, etc. }\end{array}$ \\
\hline 5 & $\begin{array}{l}\text { Financial services } \\
\text { industry }\end{array}$ & Security enhancement, Cyber risks handling, etc. \\
\hline 6 & Healthcare industry & $\begin{array}{l}\text { Mobile cloud computing, Improved healthcare, Security platform } \\
\text { for healthcare system, Cloud computing model for patient data } \\
\text { collection, Cloud healthcare as service, e-Healthcare, Cloud based } \\
\text { Hospital Information system, Medical imaging, etc. }\end{array}$ \\
\hline 7 & Hospitality industry & Smart hospitality \\
\hline 8 & Insurance industry & Cyber security insurance in Cloud computing, \\
\hline 9 & Media industry & $\begin{array}{l}\text { Service oriented architecture, Cloud storage solutions, Edge to } \\
\text { cloud virtualization. }\end{array}$ \\
\hline 10 & Retail industry & Customer behaviour analysis, Cloud based mobile commerce, \\
\hline 11 & Sports industry & Bodycloud, Prediction cloud computing demand, etc. \\
\hline 12 & Tourism industry & Smart tourism, e-tourism framework, Decision support, etc. \\
\hline 13 & $\begin{array}{l}\text { Travel \& Transport } \\
\text { industry }\end{array}$ & $\begin{array}{l}\text { Autonomous vehicular clouds, Cloud based } \\
\text { intelligent transport system, Traffic safety, etc. }\end{array}$ \\
\hline 14 & $\begin{array}{l}\text { Event management } \\
\text { industry }\end{array}$ & $\begin{array}{l}\text { Security information and event management in the cloud } \\
\text { computing infrastructure, Automated cloud computing, etc. }\end{array}$ \\
\hline
\end{tabular}

Table 9 : Digital Business \& Marketing based Service Innovation in Service Industries

\begin{tabular}{|c|c|c|}
\hline $\begin{array}{l}\text { S. } \\
\text { No. }\end{array}$ & Service Industries & Applications of Digital Business \& Marketing \\
\hline 1 & Advertising industry & $\begin{array}{l}\text { Digital media advertisement, Mobile advertising, Real time bidding, } \\
\text { Banner advertising, Online advertisement, Social media advertising } \\
\text { platforms, etc. }\end{array}$ \\
\hline 2 & Education industry & $\begin{array}{l}\text { MOOCs, SPOCs, social media, and the Cookie Monster, Digita } \\
\text { fabrication, Enterprise architectures and portals in digita } \\
\text { transformation, Virtual technology, etc. }\end{array}$ \\
\hline 3 & E-Commerce industry & $\begin{array}{l}\text { Digital platforms, Digital e-commerce adoption models, Digital } \\
\text { marketing for e-commerce, etc. }\end{array}$ \\
\hline 4 & Entertainment industry & $\begin{array}{l}\text { Mobile gaming, Digital music, Digital transformation, Digital } \\
\text { business platforms for entertainment, Online video entertainment, } \\
\text { Digital video game, Localization of digital games, Social media } \\
\text { marketing for entertainment, etc. }\end{array}$ \\
\hline 5 & Fashion industry & $\begin{array}{l}\text { Fashion bloggers as communication tools, Trend analysis, } \\
\text { Predicting purchase intensions, Interactive communication, Brand } \\
\text { building, Virtual fitting room, Handling Counterfeiting, Use of } \\
\text { social media, Digital Transformation for Fast-Fashion Brands,etc. }\end{array}$ \\
\hline 6 & $\begin{array}{l}\text { Financial } \\
\text { industry }\end{array}$ & $\begin{array}{l}\text { Blockchain finance model, Digital finance, Supervision of financial } \\
\text { markets, etc. }\end{array}$ \\
\hline 7 & Healthcare industry & $\begin{array}{l}\text { Internet based observation, Patient portals and online clinical } \\
\text { consultations, Open digital platforms, Blockchain technology in } \\
\text { healthcare, Cyber security aspects, Medical tourism, Digital } \\
\text { medicine, Cloudlet-based mobile cloud computing, R\&D and } \\
\text { clinical practice models etc. }\end{array}$ \\
\hline 8 & Hospitality industry & Digital tools for innovations, Hospitality robots, Use of digital \\
\hline
\end{tabular}




\begin{tabular}{|l|l|l|}
\hline & & social media, Digital sharing platform, Risk analysis, etc. \\
\hline 9 & Insurance industry & $\begin{array}{l}\text { Digital imaging of documents, Cyber risk management, Creative } \\
\text { contracting, Smart business networks, Blockchain based insurance } \\
\text { models, Secured claim processes, Digital insurance, etc. }\end{array}$ \\
\hline 10 & Media industry & $\begin{array}{l}\text { Digitization of Media business models, Digital social media } \\
\text { support, Digital publication, etc. }\end{array}$ \\
\hline 12 & Retail industry & $\begin{array}{l}\text { Web analytics, Strategic tool, Supply chain automation, Online } \\
\text { services, Consumer centric retailing, Web services, etc. }\end{array}$ \\
\hline 13 & Tourism industry & $\begin{array}{l}\text { Internet sports marketing, Digital games, Online sports betting, etc. } \\
\text { Social media on tourism, E-tourism, Website based tourism service, } \\
\text { Digital ecosystem in Tourism, Web marketing, Agent-based } \\
\text { cybermarketing, etc. }\end{array}$ \\
\hline 14 & $\begin{array}{l}\text { Travel \& Transport } \\
\text { industry }\end{array}$ & $\begin{array}{l}\text { Web services for travel industry, Location based services, Virtual } \\
\text { logistics, Digital lifestyle and online travel, Digital travel record, } \\
\text { Digital sustainable travel services, etc. }\end{array}$ \\
\hline
\end{tabular}

Table 10 : 3D printing Technology based Service Innovation in Service Industries

\begin{tabular}{|c|c|c|}
\hline $\begin{array}{l}\text { S. } \\
\text { No. }\end{array}$ & Service Industries & Applications of 3D printing Technology \\
\hline 1 & Education industry & $\begin{array}{l}\text { Low cost 3D printing, Anatomy education, Teacher education, } \\
\text { Design thinking \& education, Engineer design education, Additive } \\
\text { manufacturing in classroom, In pre-engineering curriculum, Tool } \\
\text { for teaching \& learning in STEAM education, etc. }\end{array}$ \\
\hline 2 & E-Commerce industry & $\begin{array}{l}\text { Mass production, Networked market place, Customized production, } \\
\text { Smart manufacturing, etc. }\end{array}$ \\
\hline 3 & Entertainment industry & $\begin{array}{l}\text { Surprise object advances for the 3D printing entertainment industry, } \\
\text { Game object advances for the 3D printing entertainment industry, } \\
\text { etc. }\end{array}$ \\
\hline 4 & Fashion industry & $\begin{array}{l}\text { In garments production, Virtual design \& production, Digital 3D } \\
\text { printing in fashion, Fashion textiles by 3D printing, Collective design } \\
\text { for 3D printing in fashion, 3D printing on textile substrates, etc. }\end{array}$ \\
\hline 5 & Healthcare industry & $\begin{array}{l}\text { 3D printing of biomaterials, 3D printing for personalized medication, } \\
\text { 3D printed medicine, 3D printing in pharmaceutical } \\
\text { and medical applications, For personalized drug delivery, Organ } \\
\text { printing, etc. }\end{array}$ \\
\hline 6 & Hospitality industry & 3D food printing. \\
\hline 7 & Retail industry & For rapid manufacturing, Personal fabrication, etc. \\
\hline 8 & $\begin{array}{l}\text { Travel \& Transport } \\
\text { industry }\end{array}$ & $\begin{array}{l}\text { Influence of 3D printing on transport, Freight miles: the } \\
\text { impact of 3D printing on transport, etc. }\end{array}$ \\
\hline
\end{tabular}

Table 11 : Internet of Things (IoT) based Service Innovation in Service Industries

\begin{tabular}{|l|l|l|}
\hline $\begin{array}{l}\text { S. } \\
\text { No. }\end{array}$ & Service Industries & Applications of Internet of Things (IoT) \\
\hline 1 & Advertising industry & $\begin{array}{l}\text { IOT as Disruptive Innovation for the Advertising Ecosystem, } \\
\text { Wireless advertising software library for distributed IOT, }\end{array}$ \\
\hline 2 & Education industry & $\begin{array}{l}\text { New education architecture, IOT learning systems, Mobile education } \\
\text { using IOT, Smart university using IOT, IoT-based flipped learning } \\
\text { platform for medical education, etc. }\end{array}$ \\
\hline 3 & E-Commerce industry & IOT for cyber security, IOT based services access for e-commerce, \\
\hline \hline
\end{tabular}




\begin{tabular}{|c|c|c|}
\hline & & IOT reference architecture for E-commerce, etc. \\
\hline 6 & $\begin{array}{l}\text { Financial services } \\
\text { industry }\end{array}$ & $\begin{array}{l}\text { Service innovations by providing new applications or upgrading the } \\
\text { existing one by providing enhanced security, Blockchain } \\
\text { convergence, Value creation through enhanced privacy, Etc. }\end{array}$ \\
\hline 7 & Healthcare industry & $\begin{array}{l}\text { IOT platform for efficient healthcare services, For smarter } \\
\text { healthcare services, For enhanced security \& privacy of healthcare } \\
\text { services, IOT to manage big data based services, Data validation } \\
\text { services in personalized healthcare, IOT based information system } \\
\text { for emergency healthcare, etc. }\end{array}$ \\
\hline 8 & Hospitality industry & $\begin{array}{l}\text { Smart hospitality using IOT, Paperless buffer management, Security } \\
\text { improvements, CRM using IOT, etc. }\end{array}$ \\
\hline 9 & Insurance industry & $\begin{array}{l}\text { Risk analysis of IOT based cyber insurance, Blockchain based for } \\
\text { digital insurance management, Self organized framework for } \\
\text { insurance using IOT, etc. }\end{array}$ \\
\hline 11 & Media industry & IoT architecture for multisensory media, etc. \\
\hline 14 & Retail industry & $\begin{array}{l}\text { Improving the customer experience, Controlling supply chain, New } \\
\text { opportunity for revenue creation, Value co-creation for customers, } \\
\text { IOT as marketing tool, etc. }\end{array}$ \\
\hline 15 & Sports industry & $\begin{array}{l}\text { Sports analytics management, Occupancy monitoring system for } \\
\text { campus sports facilities, Security issues and creation in sports, etc. }\end{array}$ \\
\hline 16 & Tourism industry & $\begin{array}{l}\text { Smart tourism, Managing mobile smart tourism destinations } \\
\text { efficiently, Independent mobility of tourists in smart cities, Geo } \\
\text { targeting for marketing tourism. }\end{array}$ \\
\hline 17 & $\begin{array}{l}\text { Travel \& Transport } \\
\text { industry }\end{array}$ & $\begin{array}{l}\text { IOT ensures efficient delivery and food safety, For smart transport, } \\
\text { Ultra low power IOT based traffic monitoring system, IoT can } \\
\text { integrate transports with } \\
\text { responses, travel behaviours,interjurisdictional } \\
\text { environmental changes, city and building ambiances, sound } \\
\text { and video, etc. }\end{array}$ \\
\hline 18 & $\begin{array}{ll}\text { Event management } \\
\text { industry }\end{array}$ & Automation including time and process of event management. \\
\hline
\end{tabular}

Table 12 : Online Ubiquitous Education \& Training Technology based Service Innovation in Service Industries

\begin{tabular}{|l|l|l|}
\hline $\begin{array}{l}\text { S. } \\
\text { No. }\end{array}$ & Service Industries & $\begin{array}{l}\text { Applications of Online Ubiquitous Education \& Training } \\
\text { Technology }\end{array}$ \\
\hline 1 & Advertising industry & $\begin{array}{l}\text { Mobile advertisement through online awareness creation, } \\
\text { Digital training with internet video advertising, Online direct-to- } \\
\text { consumer advertising, etc. }\end{array}$ \\
\hline 2 & Education industry & $\begin{array}{l}\text { Ubiquitous Educationprogrammes, MOOC, Vocational education \& } \\
\text { training, Mobile learning, Online education with global quality, } \\
\text { Online engineering education, Flexible learning toolboxes, Online } \\
\text { workforce training, etc. }\end{array}$ \\
\hline 3 & E-Commerce industry & $\begin{array}{l}\text { Awareness creation in online banking, Online training for e- } \\
\text { commerce workforce, Online education for e-commerce models, } \\
\text { etc. }\end{array}$ \\
\hline 4 & Entertainment industry & $\begin{array}{l}\text { Online educational game, Digital game-based learning, Online } \\
\text { video games for education \& learning, etc. }\end{array}$ \\
\hline 5 & Fashion industry & Global online training in fashion design sector to reduce the cost, \\
\hline
\end{tabular}


International Journal of Management, Technology, and Social

\begin{tabular}{|l|l|l|}
\hline & & Mapping e-learning courses in the fashion domain, etc. \\
\hline 6 & $\begin{array}{l}\text { Financial services } \\
\text { industry }\end{array}$ & $\begin{array}{l}\text { Customer education, Financial planning education \& training, } \\
\text { Education for financial advisors, etc. }\end{array}$ \\
\hline 7 & Healthcare industry & $\begin{array}{l}\text { MOOC on health \& medicine, Processes of e-health, Clinical } \\
\text { education \& training, Mobile health, Web-based training for public } \\
\text { health practitioners etc. }\end{array}$ \\
\hline 8 & Hospitality industry & e-learning in hospitality, Mobile learning, Web-based training, etc. \\
\hline 9 & Insurance industry & e-training, online ubiquitous service, online claim clearance, etc. \\
\hline 11 & Media industry & Web-based training in media, \\
\hline 13 & Public service industry & Public sector training, Online training, Online services, etc. \\
\hline 14 & Retail industry & $\begin{array}{l}\text { Online retail services, Online after sales services, Retail training, } \\
\text { etc. }\end{array}$ \\
\hline 15 & Sports industry & Online training in sports, \\
\hline 16 & Tourism industry & $\begin{array}{l}\text { Sharing tourism knowledge online, Simulation based tourism } \\
\text { education, E-learning applications in tourism sector, etc. }\end{array}$ \\
\hline 17 & $\begin{array}{l}\text { Travel \& Transport } \\
\text { industry }\end{array}$ & $\begin{array}{l}\text { Online intermediates, Online travel purchase processes, Travel data } \\
\text { exchange, }\end{array}$ \\
\hline 18 & $\begin{array}{l}\text { Event management } \\
\text { industry }\end{array}$ & $\begin{array}{l}\text { Online event management education, Online event management } \\
\text { training, etc. }\end{array}$ \\
\hline
\end{tabular}

Table 13 : Optical Computing Technologybased Service Innovation in Service Industries

\begin{tabular}{|l|l|l|}
\hline $\begin{array}{l}\text { S. } \\
\text { No. }\end{array}$ & Service Industries & Applications of Optical Computing Technology \\
\hline 1 & Advertising industry & $\begin{array}{l}\text { High speed computation based advertising models, Online } \\
\text { advertising, Digital advertising \& processes, Resource advertising } \\
\text { and optical research networks, Optimizing advertisement - systems } \\
\text { \& methods, etc. }\end{array}$ \\
\hline 2 & Education industry & $\begin{array}{l}\text { Optical computing alternative for high speed interconnectivity and } \\
\text { storage for global MOOC, High ending computing for education, etc. }\end{array}$ \\
\hline 3 & E-Commerce industry & Modern high performance computing for large scale e-commerce, \\
\hline 4 & Entertainment industry & $\begin{array}{l}\text { Entertainment computing, Computing at speed of light for high } \\
\text { speed entertainment, All optical devices, etc. }\end{array}$ \\
\hline 5 & Healthcare industry & High speed optical computers for healthcare applications. \\
\hline 6 & Hospitality industry & $\begin{array}{l}\text { Hospitality automation based on fully functioning robots which are } \\
\text { based on high speed optical computers. }\end{array}$ \\
\hline 7 & Insurance industry & High end computing in insurance information processing. \\
\hline 8 & Sports industry & High speed computing for video games. \\
\hline 9 & $\begin{array}{l}\text { Travel \& Transport } \\
\text { industry }\end{array}$ & Intelligent transportation systems using high speed computers. \\
\hline
\end{tabular}

Table 14 : Information Storage Technology based Service Innovation in Service Industries

\begin{tabular}{|l|l|l|}
\hline $\begin{array}{l}\text { S. } \\
\text { No. }\end{array}$ & Service Industries & Applications of Information Storage Technology \\
\hline 1 & Advertising industry & Pervasive advertising \\
\hline 2 & Education industry & Storage of information in MOOC \\
\hline 3 & E-Commerce industry & Data management, Data analytics, Huge information storage \\
\hline 4 & Entertainment industry & High density digital storage \\
\hline 5 & Fashion industry & High density digital storage \\
\hline
\end{tabular}


International Journal of Management, Technology, and Social

\begin{tabular}{|l|l|l|}
\hline 6 & Healthcare industry & High density digital storage \\
\hline 7 & Hospitality industry & High density digital storage \\
\hline 8 & Media industry & High density \&high speed digital storage \\
\hline 9 & Retail industry & High density \&high speed digital storage \\
\hline 10 & Sports industry & High density \&high speed digital storage \\
\hline 11 & $\begin{array}{l}\text { Travel \& Transport } \\
\text { industry }\end{array}$ & High density \&high speed digital storage \\
\hline
\end{tabular}

Table 15 : Virtual Reality \& Augmented Reality based Service Innovation in Service Industries

\begin{tabular}{|c|c|c|}
\hline $\begin{array}{l}\text { S. } \\
\text { No. }\end{array}$ & Service Industries & Applications of Virtual Reality \& Augmented Reality \\
\hline 1 & Advertising industry & $\begin{array}{l}\text { Augmented reality effectiveness in advertising, Personal augmented } \\
\text { reality advertising, Augmented reality 3D interactive advertisements } \\
\text { on smartphones, Exposure time and self-efficacy in augmented } \\
\text { reality advertising environments, Adoption of mobile augmented } \\
\text { reality advertisements, etc. }\end{array}$ \\
\hline 2 & Education industry & $\begin{array}{l}\text { Collaborative augmented reality in education, AR as visual and } \\
\text { spatial learning tool in technology education, VR based educational } \\
\text { games, Potential of augmented reality for teaching primary school } \\
\text { science, Augmented reality to promote collaborative and autonomous } \\
\text { learning in higher education, Virtual reality-based spatial skills } \\
\text { assessment and its role in computer graphics education, AR in } \\
\text { experimental education, In immersive training system,Educational } \\
\text { video game design, etc. }\end{array}$ \\
\hline 3 & E-Commerce industry & $\begin{array}{l}\text { Virtual fitting room augmented reality techniques for e-commerce, } \\
\text { Augmented reality E-commerce assistant system, Adoption } \\
\text { of Augmented Reality Technology for E-Commerce, etc. }\end{array}$ \\
\hline 4 & Entertainment industry & $\begin{array}{l}\text { Digital interactive entertainment, Product realization, Achieving total } \\
\text { immersion, Video games, Museum effects, Interaction techniques } \\
\text { with virtual humans, Interactive storytelling and mobile augmented } \\
\text { reality applications for learning and entertainment, Applying mixed } \\
\text { realities in entertainment, etc. }\end{array}$ \\
\hline 5 & Fashi & $\begin{array}{l}\begin{array}{l}\text { Fashinology perspective on the perception and adoption } \\
\text { of augmented reality smart glasses. }\end{array} \\
\end{array}$ \\
\hline 6 & Healthcare industry & $\begin{array}{l}\text { Digital surgical environment using VR \& AR, Patient-specific virtual } \\
\text { reality simulation, Use of virtual, augmented, and mixed reality to } \\
\text { urology, VR \& AR in dentistry, Virtual reality-assisted robotic } \\
\text { surgery simulation, Clinical utility of an Augmented Reality musical } \\
\text { software among health care professionals, Augmented reality system } \\
\text { to guide radio-frequency tumour ablation, Trauma decision-making } \\
\text { simulator in Oculus virtual reality. etc. }\end{array}$ \\
\hline 7 & Hospitality industry & $\begin{array}{l}\text { Augmented reality instructions in a hospital setting, Virtual } \\
\text { reality rehabilitation and therapy, Customer emotions study in virtual } \\
\text { restaurant, Virtual collaboration, Smart hospitality, etc. }\end{array}$ \\
\hline 8 & Media industry & Virtual studio, Virtual simulated world, Social media with virtual \\
\hline 9 & $\begin{array}{ll}\text { Online } & \text { services } \\
\text { industry } & \end{array}$ & $\begin{array}{l}\text { To enhance online service experiences, visual integration } \\
\text { of virtual content into a person's real-world environment, etc. }\end{array}$ \\
\hline 10 & Retail industry & $\begin{array}{l}\text { Social mobile augmented reality for retail,Smart retail settings via } \\
\text { mobile augmented reality shopping apps, Bringing online shopping }\end{array}$ \\
\hline
\end{tabular}




\begin{tabular}{|l|l|l|}
\hline & & $\begin{array}{l}\text { experience to offline retail through augmented reality, } \\
\text { Multisensoryaugmented reality in the context of a retail clothing } \\
\text { application,Mobile augmented reality for retail environments, etc. }\end{array}$ \\
\hline 11 & Sports industry & $\begin{array}{l}\text { VR simulation for football \& other sports, VR based training models } \\
\text { for sports \& games, etc. }\end{array}$ \\
\hline 12 & Tourism industry & $\begin{array}{l}\text { New realities: a systematic literature review on virtual } \\
\text { realityand augmented reality in tourism research, VR in tourism } \\
\text { marketing using mobile device, AR as an Innovation Tool in Digital } \\
\text { Tourism Marketing, Smart tourism, Effects of virtual reality on } \\
\text { theme park visitors' experience and behaviours, etc. }\end{array}$ \\
\hline 13 & $\begin{array}{l}\text { Travel \& Transport } \\
\text { industry }\end{array}$ & $\begin{array}{l}\text { To synthesize \& immerse virtual environmentwith no touch-points } \\
\text { to the real world, Virtual reality for travel planning,VR as a travel } \\
\text { promotional tool, VR in automotive and aerospace sector, VR as } \\
\text { travel promotion tool, etc. }\end{array}$
\end{tabular}

6. MANAGEMENT OF ICCT STRATEGIES FOR ENHANCING PRODUCTIVITY \&EFFECTIVENESS :

ICCT can be used for digital service innovations in many tertiary industry sectors as seen in previous section but planning and managing them systematically to get real benefit to fulfilling the objectives of the organization is a challenge. There are many strategies used in planning and implementation of their service products. Proper strategy should be identified and implemented in a given business organization to add values and to get expected benefits. As per one school of thought in strategic management, an organization may use five types of strategies while promoting a business which include : (i) Survival strategy or black ocean strategy [72], (ii) Sustainability strategy or green ocean strategy [73], (iii) Monopoly strategy or blue ocean strategy [74], (iv) Competitive strategy or red ocean strategy [75], and (v) Growth \& prosperous strategy or while ocean strategy [76]. These strategies can be applied to service sector industries while managing their technology adaption to promote digital service innovations (table 16).

Table 16 :Strategies to be adopted for digital Service Innovation in Service Industries

\begin{tabular}{|l|l|l|}
\hline $\begin{array}{l}\text { S. } \\
\text { No. }\end{array}$ & Service Industries & Explanation \\
\hline 1 & $\begin{array}{l}\text { Survival strategy } \\
\text { (black ocean strategy) } \\
\text { [71] }\end{array}$ & $\begin{array}{l}\text { ICCT underlying technologies to be used for survival of the } \\
\text { business. Some of the survival strategies in service industries are } \\
\text { following business plan, time management in providing promised } \\
\text { service, lobbying to promote business. Use of technology in the } \\
\text { business. }\end{array}$ \\
\hline 2 & $\begin{array}{l}\text { Sustainability strategy } \\
\text { (green ocean strategy) } \\
\text { [72] }\end{array}$ & $\begin{array}{l}\text { Study business environment and use ICCT underlying technologies } \\
\text { for business sustainability. }\end{array}$ \\
\hline 3 & $\begin{array}{l}\text { Monopoly strategy } \\
\text { [73] ocean strategy) }\end{array}$ & $\begin{array}{l}\text { Study business model and use ICCT underlying technologies to } \\
\text { radical changes in business model to kill the competition }\end{array}$ \\
\hline 4 & $\begin{array}{l}\text { Competitive strategy } \\
\text { (Red ocean strategy) }\end{array}$ & $\begin{array}{l}\text { Study \& compare service quality differentiation with competitors } \\
\text { and use ICCT underlying technologies to differentiate the services } \\
\text { quality }\end{array}$ \\
\hline 5 & $\begin{array}{l}\text { Growth \& prosperous } \\
\text { strategy } \\
\text { (While ocean strategy) }\end{array}$ & $\begin{array}{l}\text { Use ICCT underlying technologies completely to provide ideal } \\
\text { service through Automation, through intelligence, through } \\
\text { immediate supply of services ubiquitously, through lifetime }\end{array}$ \\
\hline
\end{tabular}


Service industries primarily produces intangible products as service such as customer service, management service, advice \& consultancy service, knowledge \& decision suggestions service, design \& creativity service, and services based on experience. Accordingly, there are many industries providing useful services to the users in the society. Some of the prominent service industries and the digital service innovation strategies suitable for such services using ICCT underlying technologies can be predicted.Table 17 depicts the various strategies suggested in different types of service industries to initiate and to manage digital services innovation.

Table 17: Strategies to be adopted for digital Service Innovation in Service Industries

\begin{tabular}{|l|l|l|}
\hline $\begin{array}{l}\text { S. } \\
\text { No. }\end{array}$ & Service Industries & Major Strategies suitable for digital service innovation \\
\hline 1 & Advertising industry & Survival strategy, Sustainability strategy \\
\hline 2 & Education industry & Competitive strategy, Growth \& prosperous strategy \\
\hline 3 & E-Commerce industry & Monopoly strategy, Competitive strategy \\
\hline 4 & Entertainment industry & Growth \& prosperous strategy \\
\hline 5 & Fashion industry & Growth \& prosperous strategy \\
\hline 6 & $\begin{array}{l}\text { Financial services } \\
\text { industry }\end{array}$ & Competitive strategy \\
\hline 7 & Healthcare industry & $\begin{array}{l}\text { Monopoly strategy } \\
\text { Growth \& prosperous strategy }\end{array}$ \\
\hline 8 & Hospitality industry & Competitive strategy, Growth \& prosperous strategy \\
\hline 9 & Insurance industry & Monopoly strategy, Competitive strategy \\
\hline 10 & IT services industry & Growth \& prosperous strategy \\
\hline 11 & Media industry & Survival strategy \\
\hline 12 & $\begin{array}{l}\text { Online services } \\
\text { industry }\end{array}$ & Sustainability strategy \\
\hline 13 & Public service industry & Monopoly strategy \\
\hline 14 & Retail industry & Competitive strategy \\
\hline 15 & Sports industry & Monopoly strategy \\
\hline 16 & Tourism industry & Survival strategy, Sustainability strategy \\
\hline 17 & $\begin{array}{l}\text { Travel \& Transport } \\
\text { industry }\end{array}$ & Survival strategy, Sustainability strategy \\
\hline 18 & $\begin{array}{l}\text { Event management } \\
\text { industry }\end{array}$ & Competitive strategy \\
\hline
\end{tabular}

In technology management, the organizations under various industries should identify suitable technology, plan to adopt, procure \& implement, manage, and forecast effectively and efficiently to enhance productivity. For service innovation using ICCT, identifying suitable underlying technologies for a given industry, using them for improving the attributes of the services provided like method, quality, accuracy, timeliness, efficiency, and effectiveness are important. The service innovation process must consist of improving the quality attributes of digital servicesincludingSafe \& Secure, Ubiquitous, Simple \& Easy, Customizable, Flexibility, Adaptability, Reusability, and Innovability using adopted technology.

\section{CONCLUSION :}

The various underlying technologies of ICCT are in the tertiary industry sectorare used to analyse, and predict the suitable 
technologies and suitable strategies using predictive analysis model. The potential applications of ICCT as a strategic tool for survival, sustainability, differentiation, and development of various service sector industries are identified and listed. It is found that Information Communication and Computation Technology (ICCT) is having applications in many areas of society to solve problems of society as Universal general purpose technology of $21^{\text {st }}$ century is one of the effective \& efficient technologies for digital service innovation. By identifying, implementing, and managing these digital technologies in the service sector, industries can add value to their existing services, and develop new related services to get business benefits. Thus, the progress of ICCT underlying technologies and their abilities in digital service innovation are expected to contribute the larger objective of a technology to solve basic needs, advanced wants, and dreamy desires of Human beings as well as to adopt various strategies in organizations for surviving, sustainability, monopoly, differentiation, and development through growth \& prosper.

\section{REFERENCES :}

[1] Boyan J., Peter L., Rousseau (2005). Handbook of Economic Growth, Vol. 1B. pp. 1182-1224, Edited by Philippe Aghion and Steven N. Durlauf, Elsevier B.V. DOI: 10.1016/S1574-0684(05)01018-X.

[2] Lipsey, Richard; Kenneth I. Carlaw; Clifford T. Bekhar (2005). Economic Transformations: General Purpose Technologies and Long-Term Economic Growth. Oxford University Press. pp. 131218. ISBN 0-19-928564-0.

[3] Aithal, P. S. and Shubhrajyotsna Aithal. (2018). Study of various General-Purpose Technologies and their contribution towards developing Sustainable Society. International Journal of Management, Technology, and Social Sciences (IJMTS), 3(2), 16-33. DOI:http://doi.org/10.5281/Zenodo.140947 $\underline{6}$.
[4] Aithal, P. S. (2016). Review on Various Ideal System Models Used to Improve the Characteristics of Practical Systems. International Journal of Applied and Advanced Scientific Research, 1(1), 47-56. DOI:http://doi.org/10.5281/zenodo.159749.

[5] Aithal, P. S. (2015). Concept of Ideal Business \& Its Realization Using EBusiness Model. International Journal of Science and Research (IJSR), 4(3), 1267 1274.

DOI :http://doi.org/10.5281/zenodo.61648.

[6] Aithal, P. S. \&Shubhrajyotsna Aithal, (2015). Ideal Technology Concept \& its Realization Opportunity using Nanotechnology, International Journal of Application or Innovation in Engineering \& Management (IJAIEM), 4(2), 153 - 164. DOI: http://doi.org/10.5281/zenodo.61591.

[7] Saunila, M., Rantala, T. \&Ukko, J. (2017).Characteristics of customer value creation in digital services. Journal of Service Science Research, 9(2), 239-258. DOI: https://doi.org/10.1007/s12927-0170012-4.

[8] Bharadwaj A., El Sawy O.A., Pavlou P.A., \& Venkatraman N. (2013). Digital business strategy: Toward a next generation of insights. MIS Quarterly, 37(sn2), 471-482.

[9] Salminen, J. (2014). Digital Services - How Are They Different? In Proceedings of International Conference on Business, Information, and Cultural Creative Industry (ICBIC14), Taipei, Taiwan, 6-8 August. http://jonisalminen.com/wpcontent/uploads/2018/08/digitalservices_taipei.pdf.

[10] Kitzinger, J. (1995). Qualitative research: introducing focus groups. BMJ, 311(7000), 299-

302.DOI: https://doi.org/10.1136/bmj.311.7 000.299 .

[11] Barrett, M., Davidson, E., Prabhu, J., \& Vargo, S. L. (2015). Service innovation in the digital age: key contributions and future directions. MIS quarterly, 39(1), 135-154. 
[12] Nylén, D., \&Holmström, J. (2015). Digital innovation strategy: A framework for diagnosing and improving digital product and service innovation. Business Horizons, 58(1), 57-67.

[13] Nambisan, S. (2013). Information technology and product/service innovation: A brief assessment and some suggestions for future research. Journal of the Association for Information Systems, 14(4), 1.

[14] Häikiö, J., \&Koivumäki, T. (2016). Exploring digital service innovation process through value creation. Journal of Innovation Management, 4(2), 96-124.

[15] Agarwal, R., Selen, W., Roos, G., \& Green, R. (Eds.). (2015). The handbook of service innovation. Springer.

[16] Sheehan, J. (2006). Understanding service sector innovation. Communications of the ACM, 49(7), 42-47.

[17] Löbler, H., \&Lusch, R. F. (2014). Signs and practices as resources in IT-related service innovation. Service Science, 6(3), 190-205.

[18] Bustinza, O. F., Gomes, E., Vendrell-Herrero, F., \& Baines, T. (2019). Product-service innovation and performance: the role of collaborative partnerships and $\mathrm{R} \& \mathrm{D}$ intensity. $R \& D$ Management, 49(1), 33-45.

[19] Bertot, J. C., Estevez, E., \&Janowski, T. (2016, March). Digital public service innovation: Framework proposal. Proceedings of the 9th International Conference on Theory and Practice of Electronic Governance (pp. 113-122). ACM.

[20] Hwang, J., \& Christensen, C. M. (2008). Disruptive innovation in health care delivery: a framework for business-model innovation. Health affairs, 27(5), 13291335.

[21] Hanseth, O., \&Bygstad, B. (2015). Flexible generification: ICT standardization strategies and service innovation in health care. European Journal of Information Systems, 24(6), 645-663.

[22] Voudouris, C., Owusu, G., Dorne, R., \&Lesaint, D. (2007). Service chain management: Technology innovation for the service business. Springer Science \& Business Media.

[23] Norman, D. A., \&Verganti, R. (2014). Incremental and radical innovation: Design research vs. technology and meaning change. Design issues, 30(1), 78-96.

[24] Morabito, V. (2014). Trends and challenges in digital business innovation. New York: Springer International Publishing.

[25] Bygstad, B., \&Lanestedt, G. (2009). ICT based service innovation-A challenge for project management. International Journal of Project Management, 27(3), 234-242.

[26] Kandampully, J. (2002). Innovation as the core competency of a service organisation: the role of technology, knowledge and networks. European journal of innovation management, 5(1), 18-26.

[27] Jiménez-Zarco, A. I., Martínez-Ruiz, M. P., \&Izquierdo-Yusta, A. (2011). Key service innovation drivers in the tourism sector: empirical evidence and managerial implications. Service Business, 5(4), 339.

[28] Lehrer, C., Wieneke, A., vomBrocke, J., Jung, R., \& Seidel, S. (2018). How big data analytics enables service innovation: materiality, affordance, and the individualization of service. Journal of Management Information Systems, 35(2), 424-460.

[29] Xu, X. (2012). Internet of things in service innovation. Amfiteatru Economic Journal, 14 (Special No. 6), 698-719.

[30] Rubalcaba, L., Michel, S., Sundbo, J., Brown, S. W., \& Reynoso, J. (2012). Shaping, organizing, and rethinking service innovation: a multidimensional framework. Journal of Service Management, 23(5), 696-715.

[31] Benghozi, P. J., Gille, L., \&Vallée, A. 
(2009). Innovation and regulation in the digital age: A call for new perspectives. In Telecommunication Markets (pp. 503525). Physica, Heidelberg.

[32] Madhushree L. M., Revathi Radhakrishnan \& P. S. Aithal (2019). A Review on Impact of Information Communication \& Computation Technology (ICCT) on Selected Primary, Secondary, and Tertiary Industrial Sectors. Saudi Journal of Business and Management Studies, 4(1), 106-127. ISSN 2415-6663, Scholars Middle East Publishers, Dubai, United Arab Emirates.

DOI:

http://doi.org/10.21276/sjbms.2019.4.1.14.

[33] Aithal, P. S. \&Madhushree, L. M. (2019). Information Communication \& Computation Technology (ICCT) as a Strategic Tool for Industry Sectors. International Journal of Applied Engineering and Management Letters (IJAEML), 3(2), 65-80. DOI: http://doi.org/10.5281/zenodo.3549423.

[34] Aithal, P. S. (2015). Mobile Business as an Optimum Model for Ideal Business. International Journal of Management, IT and Engineering (IJMIE), 5(7), 146-159, DOI

:http://doi.org/10.5281/zenodo.163880.

[35] Aithal P. S. and Shubhrajyotsna Aithal (2014). Ideal education system and its realization through online education model using mobile devices, Proceedings of IISRO Multi Conference 2014, 140 - 146, ISBN No. 978-81-927104-33-13. DOI: http://doi.org/10.5281/zenodo.62059.

[36] Aithal P. S. and Shubhrajyotsna Aithal (2015). An Innovative Education Model to realize IdealEducation System. International Journal of Scientific Research and Management (IJSRM), 3(3), 2464 2469.

DOI: http://doi.org/10.5281/zenodo.61654.

[37] Aithal, P. S.\&Vaikuth Pai, T. (2016). Concept of Ideal Software and its Realization Scenarios. International Journal of Scientific Research and Modern
Education (IJSRME), 1(1), 826-837. DOI:http://doi.org/10.5281/zenodo.160908.

[38] Aithal, P. S. \&Priyesh Pai, T. (2017). Opportunity for Realizing Ideal Computing System usingCloud Computing Model. International Journal of Case Studies in Business, IT and Education(IJCSBE), 1(2), 60-71. DOI: http://dx.doi.org/10.5281/zenodo.1094995.

[39] Aithal, P. S. \&Shubhrajyotsna Aithal (2015). A review on Anticipated Breakthrough Technologies of 21st Century. International Journal of Research \& Development in Technology and Management Sciences, 21(6), 112 - 133. DOI: http://doi.org/10.5281/zenodo.61617.

[40] Qi, J., Wu, F., Li, L., \& Shu, H. (2007). Artificial intelligence applications in the telecommunications industry. Expert Systems, 24(4), 271-291.

[41] Zsarnoczky, M. (2017). How does Artificial Intelligence affect the Tourism Industry?. VADYBA, 31(2), 85-90.

[42] Mehr, H., Ash, H., \& Fellow, D. (2017). Artificial intelligence for citizen services and government. Ash Cent. Democr. Gov. Innov. Harvard Kennedy Sch., no. August, $1-12$.

[43] Eletter, S. F., Yaseen, S. G., \&Elrefae, G. A. (2010). Neuro-based artificial intelligence model for loan decisions. American Journal of Economics and Business Administration, 2(1), 27.

[44] Gang, T., Kai, C., \& Bei, S. (2008, September). The research \& application of Business Intelligence system in retail industry. In 2008 IEEE International Conference on Automation and Logistics (pp. 87-91). IEEE.

[45] Sanders, N. R. (2016). How to use big data to drive your supply chain. California Management Review, 58(3), 26-48.

[46] Srivastava, U., \&Gopalkrishnan, S. (2015). Impact of big data analytics on banking sector: Learning for Indian banks. Procedia 
Computer Science, 50, 643-652.

[47] Xiang, Z., \&Fesenmaier, D. R. (2017). Big data analytics, tourism design and smart tourism. In Analytics in smart tourism design (pp. 299-307). Springer, Cham.

[48] Wang, Y., Kung, L., \& Byrd, T. A. (2018). Big data analytics: Understanding its capabilities and potential benefits for healthcare organizations. Technological Forecasting and Social Change, 126, 3-13.

[49] Erickson, S., \& Rothberg, H. N. (2016). Intangible dynamics in financial services. Journal of Service Theory and Practice, 26(5), 642-656.

[50] Lin, G., Fu, D., Zhu, J., \&Dasmalchi, G. (2009). Cloud computing: IT as a service. IT professional, (2), 10-13.

[51] Shi, A., Xia, Y., \& Zhan, H. (2010, August). Applying cloud computing in financial service industry. International Conference on Intelligent Control and Information Processing(pp. 579-583). IEEE.

[52]Khanna, P., \& Babu, B. (2012). Cloud computing brokering service: A trust framework. Cloud Computing, 206-212.

[53] Gilbert, D., \& Powell-Perry, J. (2001). Exploring developments in webbased relationship marketing within the hotel industry. Journal of Hospitality \& Leisure Marketing, 9(3-4), 141-159.

[54] Vaccaro, V. L., \& Cohn, D. Y. (2004). The evolution of business models and marketing strategies in the music industry. International journal on media management, 6(1-2), 46-58.

[55]Liaw, C. Y., \&Guvendiren, M. (2017). Current and emerging applications of 3D printing in medicine. Biofabrication, 9(2), 024102.

[56] Li, T. I. N. G. J. I. E., Aspler, J. O. S. E. P. H., Kingsland, A. R. L. E. N. E., Cormier, L. M., \& Zou, X. U. E. J. U. N. (2016). 3d printing-a review of technologies, markets, and opportunities for the forest industry. $J$.
Sci. Technol. For. Prod. Process, 5(2), 30.

[57] Da Xu, L., He, W., \& Li, S. (2014). Internet of things in industries: A survey. IEEE Transactions on industrial informatics, 10(4), 2233-2243.

[58] Shah, S. H., \& Yaqoob, I. (2016). A survey: Internet of Things (IOT) technologies, applications and challenges. In 2016 IEEE Smart Energy Grid Engineering (SEGE) (pp. 381-385). IEEE.

[59] Andersson, P., \&Mattsson, L. G. (2015). Service innovations enabled by the "Internet of Things". IMP Journal, 9(1), 85-106.

[60] Elhoseny, M., Abdelaziz, A., Salama, A. S., Riad, A. M., Muhammad, K., \&Sangaiah, A. K. (2018). A hybrid model of internet of things and cloud computing to manage big data in health services applications. Future generation computer systems, 86, 13831394.

[61] Balaji, M. S., \& Roy, S. K. (2017). Value co-creation with Internet of things technology in the retail industry. Journal of Marketing Management, 33(1-2), 7-31.

[62] Aithal, P. S., \& Aithal, S. (2015). An innovative education model to realize ideal education system. International Journal of scientific research and management (IJSRM), 3(3), 2464-2469.

[63] Barnhart, F. D., \& Pierce, J. E. (2012). Becoming mobile: Reference in the ubiquitous library. Journal of Library Administration, 52(6-7), 559-570.

[64] Lee, Y., \& Chang, H. (2012). Ubiquitous health in Korea: progress, barriers, and prospects. Healthcare informatics research, 18(4), 242-251.

[65] Feldman, M. P., \&Lendel, I. (2010). Under the lens: the geography of optical science as an emerging industry. Economic Geography, 86(2), 147-171.

[66] Zhang, Y., Chowdhury, P., Tornatore, M., \& Mukherjee, B. (2010). Energy efficiency in telecom optical networks. IEEE 
Communications Surveys \&

Tutorials, 12(4), 441-458.

[67] Navab, N. (2004). Developing killer apps for industrial augmented reality. IEEE Computer Graphics and applications, 24(3), 16-20.

[68] Lee, K. (2012). Augmented reality in education and training. TechTrends, 56(2), 13-21.

[69]Keller, B., Möhring, M., \& Schmidt, R. (2015). Augmented reality in the travel industry: a perspective how modern technology can fit consumer's needs in the service industry. Naples Forum on Services.

[70] Shubhrajyotsna Aithal \& Aithal, P. S. (2018). The Realization Opportunity of Ideal Energy System using Nanotechnology Based Research and Innovations.International Journal of Advanced Trends in Engineering and Technology, 3(2), 1-15. DOI :http://doi.org/10.5281/zenodo.2531876.

[71] Aithal, P. S.\&ShubhrajyotsnaAithal (2019). New Directions in Scholarly Research- Some Fearless Innovations \& Predictions for $21^{\text {st }}$ Century Research. International Journal of Management, Technology, and Social Sciences (IJMTS), 4(1), 1-19. DOI: http://doi.org/10.5281/zenodo.2557222.

[72] Aithal P. S., Suresh Kumar P. M., (2015). Black Ocean Strategy - A Probe into a New type of Strategy used for Organizational Success. GE International Journal of Management Research, 3(8), 45 - 65. DOI : http://doi.org/10.5281/zenodo.163423.

[73] Hou, Shengtian (2007). Green ocean strategy: Obtaining sustainable competitive advantage, Beijing: Tsinghua University Press, pp. 183-197.

[74] Kim, W. C., \& Mauborgne, R. (2005). Blue ocean strategy. California Management Review, 47(3), 105-121.

[75] Porter, M. E. (1997). Competitive strategy. Measuring Business Excellence, 1(2), 1217.

[76] Aithal, P. S. (2016). The concept of Ideal
Strategy \& its realization using White Ocean Mixed Strategy. International Journal of Management Sciences and Business Research (IJMSBR), 5(4), 171179.DOI :http://doi.org/10.5281/zenodo.161108. 